Social Work/Maatskaplike Werk Vol 50 No 2; (4)

http://socialwork.journals.ac.za/pub. http://dx.doi.org/10.15270/50-2-396

FACTORS ENABLING AND HAMPERING SOCIAL WELFARE SERVICES RENDERED TO STREET CHILDREN IN PRETORIA: PERSPECTIVES OF SERVICE PROVIDERS

Rebecca Skhosana, University of South Africa, Pretoria; Rinie Schenck, University of the Western Cape, Bellville, south Africa, Petro Botha, University of South Africa, Pretoria

Abstract

A qualitative study was conducted to develop an understanding of the social welfare services being rendered to street children in Pretoria and to ascertain what factors facilitate or hamper the rendering of these services. The research shows clearly that the funding required for ensuring the sustainability of the organisations is insufficient, and that the human resources are unstable. The article provides a critical analysis of some of the key social welfare service challenges that need to be addressed to ensure the effective and sustainable delivery of social welfare services. 


\section{FACTORS ENABLING AND HAMPERING SOCIAL WELFARE SERVICES RENDERED TO STREET CHILDREN IN PRETORIA: PERSPECTIVES OF SERVICE PROVIDERS}

\section{Rebecca Skhosana, Rinie Schenck, Petro Botha}

\section{INTRODUCTION}

According to Staker (2005) and Ennew (2005), children are often forced out of their homes because of poverty, socio-economic crises and dysfunctional family environments that may include high levels of conflict, physical, emotional or sexual abuse, and substance abuse. Sloth-Nielsen (2004) found that children are frequently orphaned or left without caregivers on account of AIDS, the migration of parents, abandonment, disputes and civil wars.

There is little accurate information on the number of street children worldwide. It is debatable whether the number of street children is growing globally or whether there is a greater awareness of street children within societies. Beazley (2011), Volpi (2003) and the Asian Development Bank (2003a) note that estimates by governments, NGOs and researchers vary widely. Beazley (2011), as well as Ward and Seager (2010), confirm that street children are difficult to count, since they are highly mobile and they do not have a stable place in which to stay.

Protecting children's wellbeing requires sufficient resources and internal capacity for, among other actions, strategic planning, policy development and execution, programme implementation, as well as monitoring and evaluation as stipulated by UNICEF (2004). Little research has focused on the social welfare services rendered to street children by service providers (Barnet, 2004; Loffel, 2008; Panther-Brick, 2003). Patel, Hochfeld, Graham and Selipsky (2008) also indicate that ample research has been conducted on street children, but there is a need for further research to assess the nature, appropriateness and extent of the social welfare services available to these children. Street Action (2010), as well as Ray, Davey and Nolan (2011), recommend that existing social welfare services for street children such as shelters, drop-in centres, institutional care and reunification programmes be reviewed.

According to the Street Action report (2010), social welfare services are well meaning but often fail the street children they set out to protect and care for, because the services provided are not coordinated, monitored or evaluated for quality. In addition, the Department of Social Development (DSD) (2010a) asserts that there is a need for integrated social welfare services that seamlessly join together parent education, child rights and protection, psychosocial stimulation, health care, nutritional supplements, sanitation and hygiene. 
The aim of this article is to describe the results of research which explored some of the factors enabling and hampering service rendering to street children in Pretoria, as experienced by the relevant service providers.

\section{RESEARCH METHODOLOGY}

To answer the research question "What factors enable and hamper service delivery to street children?" an exploratory, descriptive and contextual research design was followed. According to Bless and Higson-Smith (2006), the purpose of exploratory research is to gain a broad understanding of a situation, phenomenon, community or person. Exploration is an attempt to develop an initial, rough understanding of a particular phenomenon and to become familiar with a new phenomenon or to gain new insight into it. Babbie (2009:89) defines descriptive research as research in which the primary purpose is to "paint a picture" using words or numbers and to present a profile, a classification of types, or an outline of steps that will make it possible to answer who, when, where and how questions. This helped the researchers to describe what enables and hampers social welfare delivery to street children. Babbie (2009:89) states that contextual design seeks to avoid separating participants from the larger context within which they find themselves. Within this study's boundaries "contextual" refers to the fact that the study was conducted within its immediate context, in a specific geographical area (i.e. Pretoria, and the respective offices of the participants), and the nature and the impact of social welfare services were investigated from the context of the service providers delivering social welfare services to street children.

The study was conducted with service providers who are working with street children under the auspices of the Tshwane Alliance for Street Children (TASC). TASC is the local representative of the National Alliance for Street Children (NASC), a governmentmandated body tasked with implementing the National Programme of Action for Children, which was initiated when South Africa became a signatory to the UN Convention on the Rights of the Child in 1995. This umbrella organisation draws its members from service providers of programmes aimed at children and young people who live and work in the streets.

According to Brick (2006:136), a sample size cannot be determined at the outset of a qualitative study, but the number of participants to be included in the sample can only be known once the data have reached a point of "saturation", that is when the information being gathered becomes repetitive. In order to obtain a sample, the researcher first obtained permission to do the research from TASC. The researcher obtained all the names of NGOs involved in rendering social work services to street children in Sunnyside, Pretoria from TASC. Initially the research focused only on the Sunnyside area, but the study then expanded to other areas of Pretoria, since TASC works in and around Pretoria. The population was therefore all the organisations rendering services to street children in Pretoria. Snowball sampling was used, starting with the organisations on the TASC list and getting additional information about other organisations (Neuman, 2006). In this study ten out of the thirty NGOs listed were relevant to the study and accessible. Some NGOs had closed down. The participants included managers, social 
workers, programme coordinators and caregivers stationed at the different NGOs working with street children.

The researcher used semi-structured interviews, a digital voice recorder and note-taking techniques to record the information, with the consent of the participants. The interviews were conducted in English, isiZulu and Setswana. The data were then translated from isiZulu and Setswana into English by the researcher. An expert in language translation was consulted to ascertain whether the English translation reflected what the participants had articulated in the digital voice recorder.

The process of data analysis was completed by the first author (Skhosana) and an experienced coder.

\section{SERVICE DELIVERY TO STREET CHILDREN IN SOUTH AFRICA}

Loffel (2008) argues that in South Africa protective service delivery to street children has remained largely the responsibility of NGOs, which are funded by volunteers, given that the government alone cannot possibly address the crisis as a whole. The Department of Social Development (2010a) and Pitzl (2006) concede that NGOs have played a significant role in presenting programmes for street children, in many cases providing social welfare services that local and national governments cannot afford. Yet NGO programmes alone are not enough to reduce the number of children in the street significantly. The Department of Social Development (2011b) further claims that the NPO (NGO) sector is central to the delivery of social welfare services in South Africa.

Grundling and Grundling (2005) declare that despite all the efforts and programmes aimed at addressing the plight of street children, the needs of these children are simply not being met. They state that street children's numbers are increasing all the time as a result of a lack of sufficient resources, such as funding and trained staff, as well as thorough planning and government policies. The Department of Social Development (2009b) and (2005) claims that the NPO sector has insufficient capacity to manage its affairs and to deliver quality social welfare services. In most cases money is diverted to administrative social welfare services instead of addressing the needs of children. Earle (2008) and Lombard (2005) are of the view that the partnership between the government and NGOs comes with numerous challenges, including growing governmental control and little recognition of the efficacy of the NGOs. Lombard (2005) adds that the challenges include high case loads, which indicates a lack of resources, low salaries and discrepancies in salaries between NGOs and government social workers (Giese, 2010; Lombard, 2005).

Loffel (2008) describes the following as challenges to the delivery of social welfare services: a shortage of social workers, poor recognition of other social service practitioners, a lack of funding and high staff turnover. Velaphi (2012) highlights the fact that lack of funding makes NGOs vulnerable to collapsing. The NGOs also lose experienced staff and senior leadership to government agencies, where conditions of employment and remuneration are better. The NGOs experience high staff turnover as a result of frustration, lack of job satisfaction and low salaries. 
Budlender and Proudlock (2010) and Barberton (2006) indicate that the government budget allocations for the social welfare services in the Children's Act (Act 38 of 2005) are insufficient. Low budget allocations to implement the Children's Act (Act 38 of 2005) compromise institutional capacity to carry out programmes and fund social welfare services for children, and street children in particular. This also means that there are financial limits to these programmes and services, as well as limits as far as human resources are concerned. De Sas Kropiwnicki (2010) cautions that the present financial situation means that NGOs, which are known to be champions in rendering social welfare services to children and programmes for street children in particular, are underfunded. Therefore the quality of early intervention and prevention programmes and the social welfare services they offer are limited and are being undermined.

\section{RESULTS OF THE RESEARCH}

In the following section the results from the research will be described.

\section{Demographic data of the participants}

Table 1 presents demographic profile of the participants from the NGOs.

\section{TABLE 1}

DEMOGRAPHIC DATA OF THE PARTICIPANTS IN THE STUDY

\begin{tabular}{|l|l|l|l|c|c|}
\hline Participant & Gender & Race & Professional status & $\begin{array}{c}\text { Years of } \\
\text { experience }\end{array}$ & $\begin{array}{c}\text { Number of } \\
\text { interviews }\end{array}$ \\
\hline A & Male & Black & Site manager & 5 & 2 \\
\hline B & Female & Black & Programme coordinator & 2 & 1 \\
\hline C & Female & Black & Care worker & 2 & 2 \\
\hline D & Female & Black & Site manager & 1 & 2 \\
\hline E & Female & Indian & Manager & 10 & 2 \\
\hline F & Male & White & Programme coordinator & 2 & 1 \\
\hline G & Female & Black & Social worker & 4 & 2 \\
\hline H & Female & White & Social worker & 6 months & 1 \\
\hline I & Female & Black & Social worker & 2 & 1 \\
\hline
\end{tabular}

The gender representation of the participants was seven females and two males. The racial distribution shows five black participants, two white participants and one Indian. Three of the participants were social workers who were directly responsible for rendering social welfare services to street children. Two of the participants were working as site managers in their NGOs. There were two programme coordinators, who were responsible for overseeing the daily management of the NGOs. The programme coordinators' responsibilities were the same as those of the managers. One of the participants was a social work manager whose responsibility was to oversee and manage the work of the other categories of workers (i.e. social auxiliaries, care givers) and the affiliated NGOs.

One of the participants in the study had ten years of experience in the field of social work service rendering to street children within the context of different NGOs. The other participants' work experience ranged from six months to five years. 


\section{Discussion on themes, subthemes and categories relating to the literature}

Table 2 provides the themes which emerged from the interviews about the enabling and hampering factors in the delivery of services to street children. The last theme includes the suggestions made by the participants regarding the improvement of services.

TABLE 2

THEMES EMERGED FROM THE COLLECTED DATA

\begin{tabular}{|l|l|}
\hline $\begin{array}{l}\text { Theme 1: A profile of the NGOs } \\
\text { rendering social welfare services to } \\
\text { street children }\end{array}$ & \\
\hline $\begin{array}{l}\text { Theme 2: Factors enabling service } \\
\text { providers to render social welfare } \\
\text { services to street children }\end{array}$ & $\begin{array}{l}\text { Factor 2.1: Financial support from the Department of } \\
\text { Social Development } \\
\text { Factor 2.2: Support from the public and private } \\
\text { sector. } \\
\text { Factor 2.3: Human resources enabling the } \\
\text { organisation to render social welfare services to street } \\
\text { children in Pretoria } \\
\text { Factor 2.4: Networking with other similar } \\
\text { organisations }\end{array}$ \\
\hline $\begin{array}{l}\text { Theme 3: Factors hampering social } \\
\text { welfare service delivery to street } \\
\text { children }\end{array}$ & $\begin{array}{l}\text { Factor 3.1: Lack of sufficient funds and resources } \\
\text { Factor 3.2: Lack of a stable workforce } \\
\text { Factor 3.3: Insufficient collaboration with and support } \\
\text { from the Department of Social Development } \\
\text { Factor 3.4: Ineffective legal restrictions }\end{array}$ \\
\hline $\begin{array}{l}\text { Theme 4: Suggestions for } \\
\text { improving social welfare service } \\
\text { delivery to street children }\end{array}$ & $\begin{array}{l}\text { Suggestion 4.1: Expansion of social welfare services } \\
\text { Suggestion 4.2: Better government funding and } \\
\text { options for alternative ways of funding social welfare } \\
\text { services } \\
\text { Suggestion 4.3: Better collaboration between } \\
\text { government and NGOs } \\
\text { Suggestion 4.4: Recognition and recruitment of social } \\
\text { welfare practitioners }\end{array}$ \\
\hline
\end{tabular}

\section{THEME 1: A PROFILE OF THE NGOS RENDERING SOCIAL WELFARE SERVICES TO STREET CHILDREN}

The profile of the NGOs rendering services to street children is presented in Table 3. 
TABLE 3

DEMOGRAPHIC PROFILE OF THE NGOS RENDERING SOCIAL WELFARE SERVICES TO STREET CHILDREN IN PRETORIA

\begin{tabular}{|c|c|c|c|c|c|}
\hline NGO & $\begin{array}{l}\text { Kind of } \\
\text { organi- } \\
\text { sation }\end{array}$ & $\begin{array}{l}\text { Status of } \\
\text { registration with } \\
\text { the Department } \\
\text { of Social } \\
\text { Development }\end{array}$ & \begin{tabular}{|l|} 
Nature of \\
social welfare \\
services to \\
street \\
children \\
\end{tabular} & $\begin{array}{l}\text { Gender of the } \\
\text { beneficiaries } \\
\text { of the social } \\
\text { welfare } \\
\text { services }\end{array}$ & $\begin{array}{l}\text { Sources of } \\
\text { funding }\end{array}$ \\
\hline $\mathrm{A}$ & NGO & Registered & $\begin{array}{l}\text { Residential } \\
\text { care and drop- } \\
\text { in centre }\end{array}$ & Boys & $\begin{array}{l}\text { Donors, } \\
\text { Department of } \\
\text { Social } \\
\text { Development }\end{array}$ \\
\hline B & NGO & $\begin{array}{l}\text { Has applied for } \\
\text { registration }\end{array}$ & $\begin{array}{l}\text { Temporary } \\
\text { residential care } \\
\text { for street } \\
\text { children } \\
\end{array}$ & Girls & Donors \\
\hline $\mathrm{C}$ & NGO & Registered & $\begin{array}{l}\text { Permanent } \\
\text { foster home }\end{array}$ & Girls & $\begin{array}{l}\text { Donors, } \\
\text { Department of } \\
\text { Social } \\
\text { Development }\end{array}$ \\
\hline $\mathrm{D}$ & NGO & Registered & $\begin{array}{l}\text { Temporary } \\
\text { residential care }\end{array}$ & Girls & $\begin{array}{l}\text { Donors, } \\
\text { Department of } \\
\text { Social } \\
\text { Development }\end{array}$ \\
\hline$E$ & NGO & Not registered & $\begin{array}{l}\text { Outreach: } \\
\text { prevention and } \\
\text { early } \\
\text { intervention }\end{array}$ & Both & $\begin{array}{l}\text { Department of } \\
\text { Social } \\
\text { Development }\end{array}$ \\
\hline $\mathrm{F}$ & NGO & Registered & $\begin{array}{l}\text { Shelter and } \\
\text { drop-in centre }\end{array}$ & Boys & $\begin{array}{l}\text { Donors, } \\
\text { Department of } \\
\text { Social } \\
\text { Development }\end{array}$ \\
\hline $\mathrm{G}$ & NGO & Registered & $\begin{array}{l}\text { Shelter and } \\
\text { drop-in centre }\end{array}$ & Boys & Donors \\
\hline $\mathrm{H}$ & NGO & Not registered & $\begin{array}{l}\text { Residential } \\
\text { care }\end{array}$ & Girls & Donors \\
\hline
\end{tabular}

The nature of social welfare services offered by the NGOs referred to in Table 3 above ranges from residential care to being a shelter and drop-in centre, and offering outreach, early intervention and prevention programmes for boys and girls. According to the Department of Social Development (2010a, 2010b), social welfare services can be classified along the divide of prevention and intervention services. Intervention implies services to people who are already homeless, while prevention implies services that are aimed at preventing people from becoming homeless. The Department of Social 
Development (2010a) and Dybicz (2005) further classify social welfare services in terms of level of intervention, which can include protection, prevention, early intervention, reunification and residential care. Table 4 lists the staff employed by the NGOs as well as their responsibilities.

\section{TABLE 4 \\ STAFF EMPLOYED BY THE NGOS}

\begin{tabular}{|c|c|c|}
\hline NGO & $\begin{array}{l}\text { STAFF } \\
\text { COMPONENT }\end{array}$ & RESPONSIBILITIES \\
\hline $\mathbf{A}$ & $\begin{array}{l}\mathbf{6} \\
1 \text { full time } \\
5 \text { part time }\end{array}$ & Coordinator, psychologist, 4 volunteers \\
\hline $\mathbf{B}$ & $\begin{array}{l}3 \\
2 \text { full time } \\
1 \text { part time }\end{array}$ & Coordinator, psychologist, administrator \\
\hline $\mathbf{C}$ & 1 full time & Child and youth care worker \\
\hline $\mathbf{D}$ & $\begin{array}{l}\mathbf{4} \\
2 \text { full time } \\
2 \text { part time }\end{array}$ & Coordinator, social worker (resigned), volunteers \\
\hline $\mathbf{E}$ & $\begin{array}{l}\mathbf{4} \\
2 \text { full time } \\
2 \text { part time }\end{array}$ & $\begin{array}{l}\text { Manager, social worker, social auxiliary worker, } \\
\text { psychologist }\end{array}$ \\
\hline $\mathbf{F}$ & $\begin{array}{l}3 \\
2 \text { full time } \\
1 \text { part-time }\end{array}$ & Psychologist, social worker, volunteer \\
\hline $\mathbf{G}$ & $\begin{array}{l}\mathbf{1 4} \\
6 \text { full time } \\
6 \text { part time }\end{array}$ & $\begin{array}{l}\text { Centre manager, social worker, administrator, advice } \\
\text { officer, two care givers, house father, two cleaners, three } \\
\text { kitchen assistants, manager of the kitchen and the security } \\
\text { officer }\end{array}$ \\
\hline $\mathbf{H}$ & 5 & $\begin{array}{l}\text { One social worker, two child care workers, cook and } \\
\text { cleaner }\end{array}$ \\
\hline
\end{tabular}

From Table 4 it seems that the number of staff varies from one to fourteen; staff includes full-time and part-time workers; some organisations have social workers, while some do not. All except one service provider usually include social workers in their staff; some organisations include house mothers and some organisations include child and youth care workers. Out of the eight NGOs, four had psychologists who helped counsel the street children.

The participants maintain that they offer a holistic range of social welfare services including foster care, shelter, and child and youth care centres. This statement is confirmed by the Department of Social Development (2010a), as well as Dunn and Parry-Williams (2008), who indicate that the child and youth care centres (CYCC) are the new umbrella term for all children's homes, places of safety, schools of industry, reform schools and secure care facilities. The participants declared that the services are designed to promote the wellbeing of children by ensuring safety, achieving 
permanency, and strengthening families to care for their children successfully. The above information does not describe the quality of services rendered. The next two themes will provide a glimpse of the quality of services rendered to the street children.

\section{THEME 2: FACTORS ENABLING SERVICE PROVIDERS IN RENDERING SOCIAL WELFARE SERVICES TO STREET CHILDREN}

\section{Factor 1: Financial support from the Department of Social Development}

With reference to financial aid enabling the service organisations being studied to do their work, the participants referred to the Department of Social Development, churches and individuals, as well as companies or businesses as financial resources.

"Our main source for now is Department of Social Development subsidy, even if it is not a $100 \%$ subsidy ... I think it is $70 \%$ and we need to raise funds for the $30 \%$... they allocate a certain amount to a child. It is R400 and something a month but I cannot remember the exact figures very well. It is R45,00 a day for a child if I am not mistaken here."

"We get funding from the churches and the Department of Social Development. Every child gets money from Social Development as part of a subsidy."

The participants seemed to appreciate the support from Department of Social Development. The NGOs are only partially funded by government and they still have to raise the bulk of funds to make ends meet from international and South African donors. The participants felt that while they were known to be champions in rendering services to children and programmes for street children in particular, the reality of being underfunded compromised, limited and undermined the delivery and quality of early intervention and prevention programmes and services.

Governments have the primary responsibility to establish the conditions in which the rights of all children can be realised, and in which families and communities are able to care effectively for children as indicated by Ray et al. (2011). These authors further assert that the wide range of preventive measures depends largely on government funding to establish effective, comprehensive poverty-reduction programmes and social services that are inclusive of poor and marginalised children, families and communities.

The Policy on Financial Awards to Service Providers (Department of Social Development, 2011b) states that social welfare services in South Africa are rendered through both government and civil society organisations. Government acknowledges that organisations have the skills, expertise, infrastructure and other resources that could contribute to reconstruction, development and the provision of social welfare services. The registered organisations receive financial support through subsidisation from the South African government. Some of these NGOs have made strides in realigning their services with government policies and priorities despite the challenges emanating from the policy. 


\section{Factor 2: Support from the public and private sector}

The funds collected from churches, individuals, companies or businesses enable the NGOs to deliver services to the street children.

"We get our funding from ... individual people who sponsor us..."

“... City Property ... Pick 'n Pay, they provide funding for us."

"Most of the funding is from the donors, churches, fund raising and private volunteers. Much of the money is from overseas sponsors."

The participants also share that food, clothing and stationery are donated, which enables the services to be rendered.

"The rest is from donations ... We rely a lot on donors for food, clothes, stationery ... they are really involved and they do a lot. People just drop in and offer whatever they have at least ... a day does not go by without somebody coming to our rescue."

The participants explained that NGOs tried to overcome the problem of inadequate funding by embarking on fundraising on an ongoing basis and by negotiating contacts and contracts for financial support from individuals, corporate and foreign donors, trusts and foundations. By so doing they are able to generate funds for projects and can implement their programmes.

Giese (2008) claims that NGOs rely on government funding and their own fundraising drives to render social welfare services. This means that the organisations have to look for additional donor funding. Budlender and Proudlock (2011) affirm that NGOs are delivering services mandated by the Act; the money paid to them does not cover the full cost of providing the social welfare services. Instead, the NGOs need to find donors to make up the shortfall. Thomas de Benitez (2011) and Patel (2010) add that some NGOs have international funding to assist them with delivery of social welfare services, whilst others are dependent on government funding. The lack of adequate and consistent funding raises questions about the consistency of the availability of these services and their long-term sustainability.

\section{Factor 3: Human resources enabling the organisations to render social welfare services to street children in Pretoria}

Participants referred to the important role of social service professionals and volunteers in rendering services to street children.

"We have dedicated staff members."

"Our staff members provide the services..."

"We have volunteers that make sure that the girls are well provided for, with school clothes ... trauma counselling ... one, who is the office administrator."

"We have volunteers that help the children with their studies, soccer ... [a] few volunteers from USA embassy ... The volunteers help with the minor things at the organisation ... like fixing a broken door, repairing here and there." 
According to Earle (2008), most of the individuals volunteer to help the vulnerable children because of their desire to help and their love of children. Loffel (2008) states that volunteers are often initially the direct providers of a service before organisations become professionalised and most NPOs continue to rely to some extent on their help. Voluntary service is now being regarded as a stepping stone to future formal employment, with skills development an essential component. The Department of Social Development (2009a:7) views social workers as the key strategic resources in addressing the needs and challenges of society with their diverse knowledge and skills. Both professional and voluntary services are important for good-quality services.

\section{Factor 4: Networking with other organisations}

The importance of networking with other similar organisations is regarded by the participants as enabling, because it develops support to do their work and it facilitates sharing of resources.

"We actually have shelters around the city that we network with. Other youth development programmes from different organisations. We work hand in glove with them because when they have enough food they give us and when we also have enough we give to them. We share resources. We do refer some of the clients to them and they also do so."

"We also work ... in conjunction with civil society organisations and government institutions. We need people to help us. We have UNICEF, the Alliance...TASC, SAPS, Children's Rights Centre, Human Rights Lawyers, Pretoria Child Protection, Metro Police..."

"We network with other organisations for things like food, funding and referrals. We get funding from donors, fundraising .... Department of Social Development provide subsidy for each girl. We have churches, supermarkets and private sponsors that help us with the funding."

According to Lombard (2010), strong partnerships depend on partners and role players understanding their roles and contributions relating to their specific fields of expertise or experience. Various departments must work together to ensure the delivery of effective child protection services, including the Departments of Social Development, Justice, Education, Health, the National Prosecuting Authority (NPA) and the South African Police Service (SAPS) (Giese, 2008). These authors further caution that poor coordination between these different departments impacts negatively on the provision of effective and comprehensive child-protection services so that networking, capacity building and joint funding between service providers may be systematically promoted.

Martin (2010) states that the NGOs operate on a smaller scale and are only able to offer particular services, as alluded to by the participants. As a result, when services are not being offered at one organisation, special arrangements are made with other organisations for the children to receive other skills or services needed. Ray et al. (2011) state that the networking and coordination between organisations working in the same 
locality help to expand the range of services that organisations can offer together to different groups of children and hence enable organisations to survive.

In summary, the four critical enabling factors for the existence of the NGOs are funds from DSD, funding from the public and private sectors, good supportive human resources and the supportive networks that the NGOs create.

\section{THEME 3: FACTORS HAMPERING SOCIAL WELFARE SERVICE DELIVERY TO STREET CHILDREN}

In the next section various factors hampering social welfare service delivery to street children as expressed by the participants will be presented and discussed.

\section{Factor 1: Lack of sufficient funds/resources}

Although the NGOs are funded by the Department of Social Development and other sources, the participants referred to a lack of funds or resources as an important factor hampering the rendering of social welfare services to children:

"I think it is finance; finance is one of the main, main problems that we have because what we have is not enough ... the financial award policy has much effect on the allocation of funds to the NGOs ... there are so many challenges."

"Lack of resources especially the funds... The money that we get from Social Development is not enough to run the organisation ... We have to do fundraising ... and that take a lot of our time because we cannot focus on one thing only. The issues are mainly with salary because this place is donor funded and we do not have enough funds."

"We also get subsidy from the government, though little, because there is a lack of coordination, quality, monitoring and evaluation of the services provided to street children from our side as NGOs and the government. The lack of coordination between and among government agencies and civil society organisations leads to competition for funding."

"The biggest drawback is funding ... Government budgets for children's care and protection is extremely small or constrained. Lotto does not help anyway ... there are also delays in the transfer of funds."

The above sentiments are supported by Solomons (2012), who asserts that international funding is drying up. He cautions that should the organisations not be funded in 2013, they may have to close down. Thomas de Benitez (2011) and Dunn and Parry-Williams (2008) argue that the NGOs responsible for delivering social welfare services are poorly funded and the staff underpaid. Budlender and Proudlock (2011) remark that the subsidies provided by the Department of Social Development to NGOs do not cover the full cost or scope of the social welfare services that need to be rendered and this seems to be the biggest hurdle in proper service delivery. 


\section{Factor 2: Lack of stable workforce}

As much as the workforce was regarded as an enabling factor, the lack of a stable workforce was mentioned as a hampering factor in good service delivery by the participants:

"We are experiencing high staff turnover because remuneration is not equal, the government pays their professionals higher salaries than us."

"There is clearly not enough social workers to deal with the demands of social services. First, there is a scarcity of appropriate skills to provide social services, which impacts significantly on the delivery of prevention and early intervention services."

"It is difficult because the social workers do not stay for a long time and other staff members also do not stay because they often look for greener pastures. You find that this person will be appointed to run the programmes and suddenly he resigns or lacks passion. The main problem, I think, it is because we do not have people that stay longer. One person cannot do everything ... Lack of staff members is also a problem."

"We still do not have a social worker ... The previous one left for greener pastures. Hope things will change because as a site manager I am restricted to do some of the things ... The Children's Act (Act No. 38) of 2005 allows only social workers to undertake most of the tasks .... This, on the other hand, causes many delays in the service delivery to the boys. The lack of social workers is a huge dilemma for our organisation. I have no guidance from any social worker."

The NGOs suffer from a high turnover of staff as social workers seek to move - either into the government sector where workloads are not only slightly lighter but salary packages are also considerably better, or to careers in another country or outside the social welfare sector (Department of Social Development 2011a; Earle, 2008; Lombard, 2008). Contributing to the high staff turnover are high caseloads, inefficiency, workplace stress and anxiety, emotional burnout, and even incidents of malpractice as social work is reduced to an activity of crisis management (Earle, 2008). According to Ray et al. (2011), working effectively with street children requires a stable and experienced workforce. From the comments of the participants this is clearly not the case.

The participants stated that the salaries need to be equalised in order to retain the professionals across the provinces in the private and public welfare sectors. They further pointed to the fact that the dilemma of limited numbers of social workers being available impacts heavily on the provision of prevention and early intervention services, since the lack of capacity in the system forces social workers to prioritise the most urgent cases, neglecting prevention and early intervention services. This leads to a greater number of children requiring protection, further reducing capacity (Giese, 2010). The acute shortage of social workers and social auxiliary workers has resulted in a severe lack of 
capacity to respond to the demand for social welfare services to vulnerable children and their families (Dunn \& Parry-Williams, 2008; Giese, 2010; Loffel, 2008; Proudlock \& Jamieson, 2008; Sanchez, 2010).

\section{Factor 3: Insufficient collaboration with and support from the Department of Social Development}

The comments from the participants indicated that the lack of a collaborative relationship with the Department of Social Development as the "mother body" for all service delivery to street children is one of the biggest hampering factors in their service delivery. The participants stated:

"Poor collaboration, especially with government, is a major problem. Work allocation is not distributed equally and they have so many restrictions..."

"I must say that the collaboration between us and the government is very poor."

"You will find that sometimes there is a power struggle because our organisation does appoint its own residential social worker, but the Social Development at the same time designates its own social worker to work in the same organisation."

"The government is failing the children. There is a widespread failure to provide children with basic health care services and social services despite this being their legal right, according to the Constitution and the Children's Act (Act No. 38) of 2005."

The participants stressed the present lack of coordination and cooperation on multiple levels, especially between the government and NGOs, which was contributing to the serious difficulties experienced by the NGOs. The participants insisted that the roles of government vis-à-vis those of the NGO sector in respect of service delivery needed to be laid down and defined clearly. Schenck (2004) concurs and calls for the roles, functions and responsibilities of the social service practitioners in the public and private sectors to be clearly spelled out and defined, since lack of clarity on this issue causes role confusion, thereby leading the staff to shift their responsibilities.

According to Loffel (2012), Ray et al. (2011), as well as Patel and Hochfeld (2008), there is still much to be done to transform welfare services in South Africa. The researchers caution that NGOs are poised to cut back their services or close their doors, while an alarming number of people working in this field are being retrenched. It seems the government has so far been helpless in its efforts to resolve the problem of street children and has to date failed to come up with potential solutions for and funding to the NGOs.

\section{Factor 4: Ineffective legal restrictions}

Challenges in accomplishing the objectives of the Children's Act (Act 38 of 2005) have been identified in the area of human resources, funding and collaboration within government departments and between government and NGOs working with street children. As much as the participants understand the regulations, concerns were 
expressed that in a country with fewer resources such as funding and an effective workforce, the requirements for effective service delivery become a hampering factor instead of an enabler. The participants spoke about ineffective legal restrictions along the following lines.

"The social worker here is not allowed to do some of the work required by the organisation because of the restriction from Social Development or the Children's Act (Act No. 38) of 2005 ... The residential social worker is limited in doing some of the services, because she has to focus more on the programmes. She cannot refer or remove a child according to the Children's Act (Act No. 38) of 2005."

"I cannot appoint social auxiliary workers because they have to be supervised by the social worker and our social workers do not stay long."

"We have to comply with the norms and standards of Social Development. The Children's Act (Act No. 38) of 2005 is good on paper, but when you have to put it in practice it comes with many gaps or loopholes. For example, our outreach workers often work in Sunnyside and when they meet the child on the streets they cannot remove the child because they do not have the capacity. Our own social worker can also not remove the child because she also does not have the capacity. They have to call Social Development to remove the child and they will take forever before coming and sometimes they never show up. With the children who are being trafficked ... it is very difficult. This is not practical. What will happen with the child because we cannot keep the child safe?"

"It is the responsibility of the social worker to remove and place the child through the court order. We cannot do it ourselves. The social worker has to be designated from the Department of Social Development. We cannot use our residential social worker to do that. That is another hindering factor for service delivery, because we end up waiting for someone from the outside to render services to our organisation. It can take a period of three months or more just waiting for the response from the Department of Social Development to remove or place the child. They do the assessment and the whole procedure, according to the Children's Act (Act No. 38) of 2005."

The problems encountered with these programmes do not stem from a lack of initiative, but rather from a lack of sufficient resources, such as funding and trained staff, as well as a lack of collaboration, planning and proper implementation of government policies, as stated by Martin (2010). Budlender and Proudlock (2011:13) declare that "a social welfare service continues to be a poor third cousin despite the constitutional and legislative obligations. This is reflected in small increases in allocations, limited narrative relating to the Children's Act (Act 38 of 2005) services in the budget books, and in the ongoing funding challenges facing NGOs delivering Children's Act (Act 38 of 2005) related services".

This study reveals that inadequate specific attention is being given to the needs and circumstances of street children; practice shows that the implementation and monitoring 
stages of policy processes are weak. Not only are the guidelines and standards on how to proceed not clear, but implementing policy is also ineffective because of financial and staff constraints. Consequently some of the programmes and projects are brought to a halt, delayed or terminated, thus forcing the NGOs to close down.

\section{THEME 4: SUGGESTIONS FOR IMPROVING SOCIAL WELFARE SERVICE DELIVERY TO STREET CHILDREN}

This theme emerged from the responses of the participants. Their responses led the researcher to divide this theme into the following subthemes discussed below a suggestions.

\section{Suggestion 1: Expansion of social welfare services}

Dutschke (2008) and Earle (2008) emphasise that NGOs need to continue to provide the majority of social services, especially those involving prevention and early intervention. They also emphasise that for social welfare services to be successful, the NGOs have to be supported by government.

The participants expressed their vision of having their services expanded to other areas and put forward several suggestions.

"We are planning to have our own school, register for the youth development project, have facilities for youth development, have our own commune, as well with the aim of monitoring the children because sometimes they act irresponsibly, they finish school and get a job but end up being alcoholics."

"Our dream as the organisation is to have more efficient premises and services to cater for more vulnerable children. There is the need for professional intervention programmes to address substance abuse and trauma caused by prostitution, drug addiction and neglect. We would love to move to Sunnyside if we could ... because that is where more street children are. They are accessible and there are more resources there."

Consistent with findings by Dutschke (2008), it is clear that urban-based NGOs need to expand their services to rural areas, though it is impossible for urban-based organisations that are struggling to access funding to expand their services into rural areas without the required support from government.

"Maybe if we could expand to rural areas..."

When speaking about current social services in South Africa, Cross and Seager (2010) are of the view that these services are uncoordinated and fragmented. This becomes a major impediment to efforts to help children who have multiple needs, as is characteristic of all homeless, runaway or expelled-from-home children. According to Ward, Seager and Tamasane (2007), a range of services is essential in working with street children, including outreach work, soup kitchens, drop-in centres, shelters and homes for children who cannot be reintegrated into their families. The key ingredients for success in working with children, according to Ward et al. (2007), include the following: 
- accessible shelters, preferably placed in the communities the children came from, in order to intervene as early as possible;

- collaboration between shelters, so that children cannot play one shelter off against another;

- warm relationships with children, that enable limit-setting within a bond between the child and the programme;

- a full assessment of a child's mental and physical health needs, educational needs, and those of his or her family; and

- education appropriate to the child's needs, and psychiatric care for those children who need it.

The NGOs participating in the study also express their vision for services as explained by Ward et al. (2007), but they unlikely to reach them, given the hampering factors mentioned.

\section{Suggestion 2: Better government funding and opting for alternative ways of funding social welfare services}

Improved and equal funding was highlighted under the discussion of the enabling and the hampering factors. The following quotations refer to suggestions made by the participants for better and equal government funding.

"One other thing is that we provide the bulk of the social services to the street children and the organisation is not fully subsidised."

"We need to get more funding as NGOs from the government."

"The other problem that we have is that we are underpaid and we work abnormal hours. The government needs to provide equal remuneration of NGOs staff to be on the same level as its own staff in order to avoid losing staff members."

Ward and Seager (2010) maintain that while social welfare services are already being provided by non-governmental organisations, local and provincial government should devote attention to ensuring that the required range of services is provided and provide the cooperation, innovation and equitable funding across provinces to ensure accessible services to rural children and their families.

The participants further indicated that, though they are often underfunded and overworked, they have to develop alternative ways to make ends meet which will enable them to continue with their services.

"To set up an income-generating project for our organisation because we cannot rely on the international donors for funds. We need to have something that belongs to us that we can use to generate some money from."

"To look for local churches and donors, because it is difficult to get international donors. Maybe to network with local government." 
"The policy on funding should be revisited by all the stakeholders."

Volpi (2002) concurs with the viewpoints mentioned and underscores the fact that funding is required to sustain existing street children's programmes and to further expand existing services. The funding will also help in monitoring and evaluating the interventions and training of staff members. Volpi (2002) further declares that lobbying, advocacy and networking is a way to help NGOs overcome their isolation, and to give a stronger voice to street children themselves (Asian Development Bank 2003b; Budlender \& Proudlock, 2011; Schmidt, 2012). This will be further discussed under the following suggestion made by the participants.

\section{Suggestion 3: Better collaboration between government and NGOs}

The participants suggested better collaboration with government as a means of improving services to street children.

"There should be collaboration between different government departments at national, provincial, local levels and the NGOs."

"Poor collaboration, especially with government is a major problem. This must be addressed."

"[The Department of] Social Development needs to start to capacitate themselves. They need more human resources. If they have designated a social worker to work with us, he or she must comply with that and do his job, otherwise we have to lodge a complaint with them and this is not about an individual but the Department. Not doing their job put the lives of the children in danger and our services also suffer because of their negligence."

The participants in this research study indicated that service delivery is seen to be constrained by the poor quality of partnership between the Department of Social Development and NGOs. There is an acknowledgement that there needs to be a more systematic engagement between government and NGO service providers, and that the two sectors have complementary roles to play in the process of developing and implementing programmes for street children. Ray et al. (2011) also caution that government does not have the systems or capacity to work directly with street-involved children, though it does have an ultimate responsibility for monitoring their situation, developing action plans to address their rights and coordinating the implementation of these plans, and setting standards for services with street children. If they cannot deliver the services themselves, they should then support the NGO sector sufficiently to render the services on their behalf.

\section{Suggestion 4: Recognition and recruitment of social welfare practitioners}

The participants feared that none of the challenges that they face regarding social welfare delivery are being addressed. This has resulted in a chaotic situation, which makes it ultimately unhelpful to try and address the dire shortage of human resources. The participants articulated suggestions for recruiting and appointing more social workers: 
"We need to have more social workers in the NGO sectors to help us because it is difficult to work with people whom you are not sure as to when they will leave."

"The government has to appoint social workers on behalf of the organisation and give them better salaries."

"[The] shortage of social workers needs to be addressed. There are clearly not enough social workers to deliver the social services to vulnerable children."

The participants felt that there was still a gap between the need for and the supply of such workers. The shortages of social service professionals needed for the effective, countrywide implementation of programmes had to be addressed urgently and efficiently through enhanced deployment and capacity building. The participants articulated their suggestions as follows:

"The other professionals like the outreach workers and community development workers need to be acknowledged and recognised for the work that they do. This matter was raised at the conference held by NASC has to be looked into by both stakeholders."

"You will find that sometimes there is power struggles because our organisation does appoint its own residential social worker but Social Development at the same time designates its own social worker to work in the same organisation”.

"Work allocation is not distributed equally and they have so many restrictions, especially on our part."

UNICEF (2009) proclaims that the shortage of social workers needed for the effective, countrywide implementation of programmes targeting the most vulnerable calls for urgent measures to build capacity, particularly at local implementation level.

The various categories of practitioners needed to provide social welfare services include social auxiliary workers; probation offers; child and youth care workers; social workers; ECD workers and community development workers. All these practitioners are crucial to providing early intervention and prevention programmes, as suggested by Loffel, (2008).

\section{CONCLUSION AND RECOMMENDATIONS BASED ON RESEARCH FINDINGS}

Based on the findings, the enabling factors of funding and human resources are also the hampering factors, as they are the critical factors for the functioning and service delivery of the NGOs. The research shows clearly that the funding required for ensuring the sustainability of the organisations is insufficient, and that the human resources are unstable. It is significant that some NGOs on the database had already been closed and that its representatives could not be interviewed. NGOs rendering services to street children seem to be in serious trouble, which will affect the beneficiaries and the quality of the services. It is also of concern that, given the scarce available resources, attention is not devoted to proper planning and coordination of services and resources. 
Duplication and inefficient application of services and resources were evident. It is therefore important that both the policies and their application be reviewed, implemented as planned, and then monitored and evaluated for effectiveness. Of concern are the experiences by the respondents of a lack of collaboration between the government and the NGOs as the government is the head and the NGO the heart and hands of the body of services delivered to street children. The lack of collaboration between the government and the NGOs results in the street children not being served effectively. Clear memorandums of understanding and/or service-level agreements to enhance collaboration in order to clarify the roles of government and NGOs may assist in role clarification, improved collaboration and effective networking.

The seeming powerlessness of the NGO sector vis-à-vis the Department of Social Development and other government structures is a matter of concern to the authors. One wonders how the NGOs can revisit their position, policies and processes to regain power and control over the services in which they are regarded as the experts.

\section{REFERENCES}

ASIAN DEVELOPMENT BANK. 2003a. ADB-Government-NGO Cooperation: a framework for action. 2003-2005. Manila: ADB.

ASIAN DEVELOPMENT BANK. 2003b. Working with children living and working in the street. Exploring ways for ADB Assistance. Manila: ADB.

BABBIE, E. 2009. The practical of social research $\left(9^{\text {th }}\right.$ ed). Australia, Belmont: CA, Wadsworth.

BARBERTON, C. 2006. The cost of the Children's Bill: estimates of the cost to government of the services envisaged by the Comprehensive Children's Bill for the period 2005 to 2010. Pretoria: Cornerstone Economic Research.

BARNET, N.A. 2004. Child, family, community and socialisation. London: Harcourt Brace College Publishers.

BEAZLEY, H. 2011. Voices from the margins: Street children's sub-cultures in Indonesia. Children's Geographies, 1(2):181-200.

BLESS, C. \& HIGSON-SMITH, C. 2006. Fundamental social research methods: an African perspective $\left(4^{\text {th }}\right.$ ed). Cape Town: Juta. 
BRICK, H. 2006. Fundamentals of research methodology of health care professionals. Cape Town: Juta.

BUDLENDER, D. \& PROUDLOCK, P. 2010. The Children's Act has commenced: Are the 2010/11 budgets of the provincial departments of social development adequate to implement it? Children's Institute, University of Cape Town.

BUDLENDER, D. \& PROUDLOCK, P. 2011. Funding the Children's Act: assessing the adequacy of the 2011/12 budgets of the provincial departments of social development. Children's Institute, University of Cape Town.

CHILDREN'S ACT (ACT NO 38) OF 2005. Pretoria: Government Gazette.

CROSS, C. \& SEAGER, J.R. 2010. Towards identifying the causes of South Africa's street homelessness: Some policy recommendations. Development Southern Africa, 27(1):143-158.

DE SAS KROPIWNICKI, Z. 2010. Identification and assessment of early intervention and prevention programmes in South Africa: desk review. Draft. Department of Social Development \& UNICEF.

DEPARTMENT OF SOCIAL DEVELOPMENT. 2005. An impact assessment of the NPO Act, No. 71 of 1997. Pretoria: Government Printer.

DEPARTMENT OF SOCIAL DEVELOPMENT. 2009a. Developing good governance practices within the South African NPO sector. Pretoria: Government Printer.

DEPARTMENT OF SOCIAL DEVELOPMENT. 2009b. The State of NPO registration South Africa. A report from the National NPO database. Pretoria: Government Printer.

DEPARTMENT OF SOCIAL DEVELOPMENT. 2010a. Strategy and guidelines for children living on and of the streets. Pretoria: Government Printer.

DEPARTMENT OF SOCIAL DEVELOPMENT. 2010b. National policy framework and strategy. Pretoria: Government Printer. 
DEPARTMENT OF SOCIAL DEVELOPMENT. 2011a. Draft reviewed framework for developmental social welfare services. Pretoria: Government Printer.

DEPARTMENT OF SOCIAL DEVELOPMENT. 2011b. Policy on financial awards to service providers. Pretoria. Government Printer.

DUNN, A. \& PARRY-WILLIAMS, J. 2008. Alternative care for children in Southern Africa: progress, challenges and future directions. ESARO Working Paper, Nairobi: UNICEF.

DUTSCHKE, M. 2008. Developmental social welfare policies and children's right to social services. In: PROUDLOCK P., DUTSCHKE M., JAMIESON, L., MONSON J. \& SMITH, C. (eds) South African Child Gauge, 2007/2008, 29-34.

DYBICZ, P. 2005. Interventions for street children: an analysis of current best practices. International Social Work, 48(6):763-771.

DYBICZ, P. 2012. The ethnic of care: recapturing social work's first voice. Social Work Advance: Journal of the National Association of Social Workers, 57(3):271280.

EARLE, N. 2008. Social work in social change: the profession and education of social workers in South Africa. Pretoria: HRSC.

ENNEW, J. 2005. Prisoners of childhood: Orphans and economic dependency. In: QVORTRUP, J. (ed). Studies of modern childhood: society, agency and culture. London: Palgrave, 128-146.

GIESE, S. 2010. Identification and assessment of early intervention and prevention programmes in South Africa: rapid review of legal and policy documents pertaining to prevention and early intervention services in South Africa. Department of Social Services \& UNICEF.

GIESE, S. 2008. Setting the scene for social services: The gap between service need and delivery. In: PROUDLOCK, P., DUTSCHKE, M., JAMIESON, L., MONSON, J., \& SMITH, C. (eds), South African child gauge. Cape Town: Children's Institute, University of Cape Town, 17-22. 
GRUNDLING, J.P. \& GRUNDLING, I.D. 2005. The concrete particulars of the everyday realities of street children. Human Relations, 58(2):173-190.

LOFFEL, J. 2008. Developmental social welfare and the child protection challenge in South Africa. Practice, 20(2):83-91.

LOMBARD, A. 2005. Impact of social services on human, social and economic development and the promotion of human rights in South Africa. Social Work/Maatskaplike Werk, 41(3):209-227.

LOMBARD, A. 2008a. The implementation of the White Paper for Social Welfare: a ten-year review. The Social Work Practitioner-Researcher, 20(2):154-173.

LOMBARD, A. 2010. Developmental social work in South Africa and Kenya: some lessons for Africa. The Social Work Practitioner-Researcher, 98-111.

MARTIN, P. 2010 Government-funded programmes and services for vulnerable children in South Africa. Cape Town: HSRC.

NEUMAN, W.L. 2006. Social Research methods: qualitative and quantitative approaches. Michigan: Pearson/Allyn and Bacon.

PANTHER-BRICK,C. 2003. Street children, human rights and public health: a critique and future directions. Children, Youth and Environments, 13(1):147-171.

PATEL, L. \& HOCHFELD, T. 2008. Indicators, barriers and strategies to accelerate the pace of change to developmental welfare in South Africa. The Social Work Practitioner-Researcher, 20(2):192-211.

PATEL, L. 2010. Pointers for future research on gender and care in voluntary organisations in Southern Africa. The Social Work Practitioner-Researcher (Special Issue), (April):39-53.

PATEL, L., HOCHFELD, T., GRAHAM, L. \& SELIPSKY, L. 2008. The implementation of the White Paper for Social Welfare in the NGO sector. Johannesburg: CSDA Report. 
PITZL, G.R. 2006. Street children. Encyclopedia of World Poverty. Sage Publications.

PROUDLOCK, P. \& JAMIESON, L. 2008. The Children's Act (Act No 38) of 2005: Providing a strong legislative foundation for a developmental approach to child care and protection. In: PROUDLOCK, P., DUTSCHKE, M., JAMIESON, L. \& MONSON, J.C. (eds). South African child gauge 2007/2008. Cape Town: Children's Institute. University of Cape Town.

RAY, P., DAVEY, C. \& NOLAN, P. 2011. Still on the street - still short of rights: analysis of policy and programmes related to street involved children. Text. Plan and Consortium for Street Children. British Library Cataloguing in Public Data.

SANCHEZ, D. 2010. Civil society responses to homelessness. Development Southern Africa, 27(1):101-110.

SCHENCK, C.J. 2004. Working conditions for social workers in rural areas in South Africa. The Social Worker Practitioner Researcher, 16(2):181-199.

SCHMIDT, J. 2012. Trends in South African Child Welfare from 2001-2010. CSDA Research Report. Johannesburg: Centre for Social Development in Africa, University of Johannesburg.

SLOTH-NIELSEN, J. 2004. Realising the rights of children growing up in childheaded households. Cape Town: University of the Western Cape, Community Law Centre.

SOLOMONS, M. 2012. Focus Programme. SABC 2. Aired on 20 October 2012.

STAKER, S.R. 2005. Street and working children. London. Paper Bross.

STREET ACTION. 2010. Including street children: situation analysis of street children in Durban. South Africa. Executive summary report 2010.

THOMAS DE BENITEZ, T. 2011. State of the world's street children. Hobbs, Southampton: Report Research. 
UNICEF. 2004. The framework for the protection, care and support of orphans and vulnerable children living in a world with HIV and AIDS. New York: UNICEF.

VELAPHI, S. 2012. NGOs in crisis over lack of funding and staff losses. The New Age, August.

VOLPI, E. 2002. Street children: promising practices and approaches. World Bank Institute.

VOLPI, E. 2003. Children living and working in the street: promising practices and approaches. Child, Youth and Environments, 13(1):1-30.

WARD, C.L. \& SEAGER, J.R. 2010. South African street children: a survey and recommendations for services. Development Southern Africa, 27(1):85-100.

WARD, C.L., SEAGER. J. \& TAMASANE, T. 2007. Street children. Report to the Department of Social Development. Pretoria: HSRC.

Ms Rebecca Skhosana, Department of Social Work, University of South Africa; Professor Rinie Schenck, Department Social Work, University of the Western Cape; Ms Petro Botha, Department of Social Work, University of South Africa, Pretoria, South Africa. 